\title{
PRAWA I OBOWIĄZKI ALUMNÓW W STATUCIE I REGULAMINIE PAPIESKIEGO KOLEGIUM POLSKIEGO W RZYMIE Z 1960 R.
}

Treść: Wstęp. - 1. Formacja duchowa. - 2. Studia. - 3. Zasady zachowania dyscypliny. -3.1 . Normy ogólne. -3.2 . Porządek dzienny. -3.3 . Obowiązki alumna względem personelu Kolegium i studentów. - Zakończenie.

\section{Wstęp}

Papieskie Kolegium Polskie w Rzymie utworzono w 1866 r. W tym samym roku został zatwierdzony Regulamin, w którym określono status prawny i zasady funkcjonowania tej instytucji, wiele miejsca poświęcono również prawom i obowiązkom alumnów. Przepisy te prawie się nie zmieniły przez sto lat, chociaż w 1894 r. wydano w Krakowie Przepisy Kolegium Polskiego w Rzymie ${ }^{1}$, gdzie powtórzono normy z pierwszego Regulaminu Kolegium. Kilkanaście lat później, w 1909 r., opublikowano jeszcze Regolamento per gli alunni del Pontificio Collegio Polacco in Roma ${ }^{2}$, gdzie sprecyzowano procedurę przyjmowania alumnów i wprowadzono możliwość korzystania $\mathrm{z}$ darmowych stypendiów przez studentów ze wszystkich polskich diecezji, a także określono roczny koszt utrzymania studenta.

\footnotetext{
${ }^{1}$ Por. Przepisy Kolegium Polskiego w Rzymie, Kraków 1894. Archiwum Papieskiego Kolegium Polskiego w Rzymie (skrót: APKP). Archiwum I (skrót: I), sygn. 26.

2 Por. Regolamento per gli alumni del Pontificio Collegio Polacco, Roma 1909. APKP, sygn. I 27.1.
} 
Dopiero pod koniec 1960 r. Stolica Apostolska zatwierdziła nowy Statut i Regulamin Papieskiego Kolegium Polskiego w Rzymie ${ }^{3}$, a kardynał Stefan Wyszyński, Prymas Polski, przesłał rektorowi, ks. prałatowi Władysławowi Rubinowi, uwierzytelniony odpis tych dokumentów z prośbą o publiczne odczytanie alumnom ich treści i zabezpieczenie uwierzytelnionej kopii w archiwum Kolegium ${ }^{4}$. Statut z 1960 r. określił Papieskie Kolegium Polskie instytucją posiadającą kościelną osobowość prawną, która ma za zadanie kształcenie i przygotowywanie studentów z polskich diecezji do przyjęcia święceń kapłańskich ${ }^{5}$.

Niniejszy artykuł jest próbą przedstawienia praw i obowiązków ${ }^{6}$ alumnów Papieskiego Kolegium Polskiego w Rzymie, określonych w Statucie i Regulaminie z końca 1960 r.

\section{Formacja duchowa}

W Regulaminie ${ }^{7} z 1960$ r. zwrócono szczególną uwagę na znaczenie formacji duchowej alumnów już od pierwszych dni ich pobytu w Ko-

${ }^{3}$ Dekret. Sacra Congregatio de Seminariis et Studiorum Universitatibus (uwierzytelniony odpis). Rzym, 12-12-1960. Prot. Num. 493/60. APKP, Archiwum III (skrót: III), sygn. 28.2.

${ }^{4}$ List. Kard. S. Wyszyński do ks. W. Rubina. Warszawa, 14-02-1961. APKP, sygn. III 28.2. Do listu załączono uwierzytelnione odpisy: listu Kongregacji skierowanego do Prymasa Polski, Statutu i Regulaminu (kard. S. Wyszyński w liście mówi tylko o Statucie) Papieskiego Kolegium Polskiego oraz dekretu Kongregacji zatwierdzającego Statut i Regulamin. Dokumenty te zostały zredagowane w języku łacińskim.

${ }^{5}$ Pkt 2, Statuta Pontificii Collegia Polonorum in Urbe (uwierzytelniony odpis). Rzym, 12-12-1960. Ad N. 3217/60/P. APKP, sygn. III 28.2, s. 1.

${ }^{6}$ Zasady przyjmowania i usuwania alumnów w Papieskim Kolegium Polskim w Rzymie po 1960 r. autor przedstawił w artykule Statut i Regulamin Papieskiego Kolegium Polskiego w Rzymie z 1960 r. (zadania instytucji, zasady funkcjonowania, personel), opublikowanym w czasopiśmie Perspectiva - Legnickie Studia Teologiczno-Historyczne, 20(2012), $\mathrm{nr} 1$.

7 Regulamin podzielono na cztery części: O przyjęciu (pkt 1-4), O formacji duchowej (pkt 5-13), O studiach (pkt 14-20), O dyscyplinie (pkt 21-51) i dodano dwa punkty zakończenia (pkt. 52-53). Tytuły kolejnych części i zakończenia w oryginale brzmią następująco: De Admissione, De Formatione Spirituali, De Studiis, De Disciplina, Epilogus. Por. Regulae ab alumnisPontificii Collegia Polonorum in Urbe servandae (uwierzytelniony odpis). Rzym, 12-12-1960. Ad N. 3217/60/P. APKP, sygn. III 28.2, s. $1-14$. 
legium. Podkreślono, że w misji powołania bardzo ważną rolę odgrywa dążenie kleryka czy kapłana do świętości poprzez prowadzenie odpowiedniego życia duchowego. Można to osiagnąć poprzez czyste życie w łączności z Bogiem, a także przez rozwijanie pozytywnych cech $^{8}$. Według norm zawartych w Statucie alumni powinni odznaczać się powołaniem do służby Bożej, wzorowo postępować, mieć nieskazitelny charakter, dobre zdrowie i potrzebne zdolności. Kandydatów z takimi przymiotami biskupi diecezjalni delegowali na studia do Rzymu9 . Należy w tym miejscu podkreślić, że od zakończenia II wojny światowej do Papieskiego Kolegium Polskiego przyjmowano również kapłanów, a od roku akademickiego 1963-1964 zamieszkiwali w tej instytucji wyłącznie księża, którzy podejmowali studia specjalistyczne w papieskich uczelniach rzymskich ${ }^{10}$.

Kapłani zamieszkujący w Kolegium byli zobowiązani do nieustannego pogłębiania życia duchowego i wytrwałego zdobywania wiedzy intelektualnej, zgodnie z zasadami określonymi przez Stolicę Apostolską i swoich biskupów, czynienia wszystkiego dla chwały Bożej, zbawienia dusz i dobra ojczyzny ${ }^{11}$. Księża, codziennie o ustalonej godzinie, mieli obowiązek celebrować Mszę św., po niej odprawiać dziękczynienie trwające około kwadransa ${ }^{12}$. Wszyscy studenci na początku każdego roku zobowiązani byli do odbycia rekolekcji trwających pięć pełnych dni, czyli trzech dni mniej w stosunku do poprzednio obowiązujących uregulowań ${ }^{13}$. Raz w miesiącu, w wyznaczonym dniu, odbywał się dzień skupienia, a ojciec duchowny wygłaszał konferen-

8 Por. pkt 5, tamże, s. 2.

9 Pkt 11, Statuta Pontificii Collegia Polonorum in Urbe (uwierzytelniony odpis). Rzym, 12-12-1960. Ad N. 3217/60/P. APKP, sygn. III 28.2, s. 2.

${ }^{10}$ Por. Listy i Wykazy alumnów Kolegium, 23-11-1953, 20-10-1954, 30-10-1959, 03-11-1960, 23-03-1962, 08-09-1963, 29-01-1964, 17-05-1965. APKP, sygn. III 39.

${ }^{11}$ Pkt 6, Regulae ab alumnis Pontificii Collegia Polonorum in Urbe servandae (uwierzytelniony odpis). Rzym, 12-12-1960. Ad N. 3217/60/P. APKP, sygn. III 28.2, s. 2-3.

${ }^{12}$ Pkt 11, tamże, s. 4.

${ }^{13}$ Według norm zawartych w pierwszym Regulaminie Kolegium z 1866 r., każdy alumn powinien raz w roku odprawić rekolekcje trwające osiem pełnych dni. Art. $3, \S$ 1, pkt 3, Regolamento del Pontificio Collegio Polacco. Istituto in Roma, Roma 1866. APKP, sygn. I 25.1, s. 9 . 
cję. Wszyscy alumni mieli obowiązek obecności na liturgii „Godziny świętej"14. Co najmniej raz w tygodniu mieli przystępować do sakramentu pokuty u wybranego spowiednika lub kierownika duchowego, z zachowaniem postanowień kan. $1361 \mathrm{KPK}^{15}$. Pierwszy Regulamin stanowił, że alumni powinni to robić przynajmniej raz w ciągu piętnastu dni ${ }^{16}$. Czas ten został więc skrócony o ponad połowę.

Do obowiązków studentów, którzy nie byli kapłanami, należało: uczestniczenie w codziennej Mszy św. i odprawianie dziękczynienia trwającego przynajmniej kwadrans, częste przystępowanie do Komunii św., odmawianie codziennych modlitw, w tym modlitwy brewiarzowej, uczestniczenie w cotygodniowym błogosławieństwie Najświętszym Sakramentem i recytowanie litanii. Każdego dnia po obiedzie i kolacji studenci wspólnie nawiedzali Najświętszy Sakrament, byli również zachęcani do częstego nawiedzania prywatnego ${ }^{17}$.

Regulamin stanowił, że alumni powinni odznaczać się nabożeństwem do Serca Jezusowego i Najświętszej Maryi Panny i odmawiać Różaniec „z miłością i synowskim oddaniem dla swojej Matki”18. Nakazane praktyki religijne, wspólne czy prywatne, miały być odprawiane z pobożnością i godnością w Kolegium, kościołach rzymskich albo $\mathrm{w}$ innych miejscach świętych ${ }^{19}$.W omawianych dokumentach, w po-

${ }^{14}$ Pkt 7-8, Regulae ab alumnis Pontificii Collegia Polonorum in Urbe servandae (uwierzytelniony odpis). Rzym, 12-12-1960. Ad N. 3217/60/P. APKP, sygn. III 28.2, s. 3.

15 “Can. $1361 \S$ 1.Praeter confessarios ordinarios alii confessarii designentur ad quos libere alumni accedere possint. $\S 2$. Si ii confessarii extra Seminarium degant, et alumnus aliquem eorum acciri postulet, illum rector arcessat, nullo modo petitionis rationem inquirens neque se aegre id ferre demonstrans; si in Seminario habitent, ipsos alumnus libere adire potest, salva Seminarii disciplina.§ 3. Quando agitur de alumno ad ordines admittendo vel e Seminario expellendo, nunquam confessariorum votum exquiratur'. CIC 1917, w: AAS 9 II (1917), s. 264.

${ }^{16}$ Art. 3, § 1, pkt 3, Regolamento del Pontificio Collegio Polacco. Istituto in Roma, Roma 1866. APKP, sygn. I 25.1, s. 9.

${ }^{17}$ Pkt 9-10, Regulae ab alumnis Pontificii Collegia Polonorum in Urbe servandae (uwierzytelniony odpis). Rzym, 12-12-1960. Ad N. 3217/60/P. APKP, sygn. III 28.2, s. 3-4.

${ }^{18}$ Pkt 12, tamże, s. 4.

${ }^{19}$ Pkt 13, tamże, s. 5. 
równaniu do Regulaminu z 1866 r., dodatkowo zobowiązano studentów do szczególnego nabożeństwa ku czci Serca Jezusowego ${ }^{20}$.

\section{Studia}

Alumni przygotowujący się do kapłaństwa, oprócz pracy nad swoim rozwojem duchowym, zobowiązani byli poświęcić się wymaganym studiom filozoficznym i teologicznym, zachowując depozyt wiary, zgodnie z normami i zasadami obowiązującymi w Kościele, które uprzednio musiały być przez nich dokładnie poznane, zrozumiane i zaakceptowane. Tej pracy byli zobligowani poświęcać wszystkie siły i zdolności, aby sprostać zadaniom, które stawiali przed nimi ich biskupi. Studenci uczyli się rezygnować z własnych dążeń i z pokorą poświęcać się pracy na większą chwałę Bożą i dla zbawienia dusz. W swych wysiłkach nie mogli poprzestawać na opanowaniu wiedzy w stopniu minimalnym, ale cały czas pracować nad swym rozwojem intelektualnym ${ }^{21}$.

Mieszkańcy Kolegium mogli studiować na Uniwersytecie Gregoriańskim lub na innych uczelniach kościelnych w Rzymie ${ }^{22}$. Nastapiła tutaj zmiana, gdyż od początku XX w. obowiązywała zasada, że alumni mogli podejmować studia tylko na Uniwersytecie Gregoriańskim ${ }^{23}$. Omawiany Regulamin rozszerzył możliwość odbywania studiów na inne rzymskie papieskie uczelnie kościelne ${ }^{24}$. Zakres studiów jednak zawsze musiał być konsultowany z rektorem Kolegium, a każde nowe

\footnotetext{
${ }^{20}$ Por. art. $3, \S 1$, pkt 1, Regolamento del Pontificio Collegio Polacco. Istituto in Roma, Roma 1866. APKP, sygn. I 25.1, s. 9.

${ }^{21}$ Pkt 14, Regulae ab alumnis Pontificii Collegia Polonorum in Urbe servandae (uwierzytelniony odpis). Rzym, 12-12-1960. Ad N. 3217/60/P. APKP, sygn. III 28.2, s. 5.

${ }^{22}$ Pkt 15, tamże, s. 5-6.

${ }^{23}$ Por. M. Stęrené, Przepisy i Regulamin alumnów Papieskiego Kolegium Polskiego w Rzymie z przełomu XIX i XX wieku, Perspectiva 19(2011), nr 2, s. 306-307.

${ }^{24}$ Regulamin wydany w 1909 r. przewidywał identyczny cykl studiów jak pierwszy Regulamin z 1866 r., czyli dwa lata filozofii, cztery lata teologii i kurs prawa. Jedyną różnicę stanowi zobowiązanie do studiowania wyłącznie na Uniwersytecie Gregoriańskim. Por. pkt 62, Regolamento per gli alumni del Pontificio Collegio Polacco, Roma 1909. APKP, sygn. I 27.1, s. 10; art. 3, § 2, pkt 1, Regolamento del Pontificio Collegio Polacco. Istituto in Roma, Roma 1866. APKP, sygn. I 25.1, s. 9-10.
} 
zajęcie uniwersyteckie lub domowe, w tym również powtarzanie roku, można było podjąć tylko po uzyskaniu jednoznacznej zgody rektora ${ }^{25}$. W Regulaminie z 1960 r. sugerowano, aby studenci posługiwali się językiem polskim, doskonaląc go w piśmie i mowie, oraz często korzystali z języka łacińskiego i włoskiego ${ }^{26}$. Natomiast tuż po utworzeniu Kolegium w połowie XIX w. nakazywano w Regulaminie, by alumni posługiwali się przede wszystkim językiem włoskim i łacińskim, a tylko za zgodą rektora rozmawiali w języku ojczystym ${ }^{27}$. Nastappiła tu zasadnicza zmiana.

Omawiany Statut i Regulamin z 1960 r. odnosił się przede wszystkim do alumnów przygotowujących się do przyjęcia święceń kapłańskich, dlatego położono w nim nacisk na studia filozoficzne i teologiczne. Należy jednak zaznaczyć, o czym już wspomniano wyżej, że od 1963 r. w Papieskim Kolegium Polskim zamieszkiwali wyłącznie księża kierowani na studia do Rzymu przez swoich biskupów ${ }^{28}$.W konsekwencji, przez prawie cały okres obowiązywania Statutu i Regulaminu z 1960 r., w Kolegium zamieszkiwali kapłani, którzy studiowali

${ }^{25}$ Pkt 16-17, Regulae ab alumnis Pontificii Collegii Polonorum in Urbe servandae (uwierzytelniony odpis). Rzym, 12-12-1960. Ad N. 3217/60/P. APKP, sygn. III 28.2, s. 6.

${ }^{26}$ Pkt 20, tamże.

${ }^{27}$ Por. art. 10, pkt 28, Regolamento del Pontificio Collegio Polacco. Istituto in Roma, Roma 1866. APKP, sygn. I 25.1, s. 35. W Regulaminie z 1866 r. nakazano używanie na przede wszystkim języka włoskiego i łacińskiego. Por. M. STĘPIEŃ, Prawa i obowiazki alumnów w Regulaminie Papieskiego Kolegium Polskiego w Rzymie z 1866 r., Prawo Kanoniczne 55(2012), nr 1, s. 93.

${ }^{28}$ Por. Listy i Wykazy alumnów Kolegium, 23-11-1953, 20-10-1954, 30-10-1959, 03-11-1960, 23-03-1962, 08-09-1963, 29-01-1964, 17-05-1965. APKP, sygn. III 39. Por. pkt 15, Regulae ab alumnis Pontificii Collegia Polonorum in Urbe servandae (uwierzytelniony odpis). Rzym, 12-12-1960. Ad N. 3217/60/P. APKP, sygn. III 28.2, s. 5-6. Preferowanie Uniwersytetu Gregoriańskiego miało swoje źródło w Regulaminie Kolegium wydanym w 1909 r., gdzie zobowiązano alumnów do studiowanie wyłącznie na Uniwersytecie Gregoriańskim, co było związane z bardzo dobrą opinią jaką wówczas cieszył się ten uniwersytet. Regolamento per gli alumni del Pontificio CollegioPolacco, Roma 1909. APKP, sygn.I 27.1; por. M. STĘPIEŃ, Przepisy i Regulamin alumnów Papieskiego Kolegium Polskiego w Rzymie z przełomu XIX i XX wieku, Perspectiva 19(2011) nr 2, s. 306-307. 
różne dyscypliny wskazane przez ich własnych biskupów, a nie klerycy, przygotowujący się do przyjęcia święceń i studiujący filozofię, teologię oraz prawo, jak to precyzował pierwszy Regulamin Kolegium z połowy XIX w. ${ }^{29}$

\section{Zasady zachowania dyscypliny}

Statut z 1960 r. przewidywał funkcję kardynała protektora i dwóch tzw. deputatów, z których jeden zajmował się sprawami administracyjnymi, a drugi zasadami zachowania dyscypliny w Kolegium. Deputatami byli księża mianowani przez Kongregację na okres sześciu lat ${ }^{30}$. Ustanowiona $\mathrm{w}$ omawianych dokumentach kadencyjność nominacji deputatów była nowością. Regulamin z 1866 r. stanowił, że nad funkcjonowaniem Kolegium czuwał kardynał protektor, któremu pomocą służyli dwaj deputaci przez niego mianowani spośród duchowieństwa rzymskiego, ale bez określenia kadencyjności. Do zadań deputatów należało: dbanie o przestrzeganie dyscypliny, zajmowanie się bieżącą administracją Kolegium, wypełnianie obowiązków określonych przez kardynała protektora. Oprócz tego byli oni zobowiązani wizytować Kolegium nie mniej niż jeden raz na piętnaście dni. Alumni w czasie takiej wizytacji mieli prawo przedstawić swoją sytuację, prosić o po$\operatorname{moc}^{31}$.

Czwartą część Regulaminu z 1960 r. poświęcono dyscyplinie i podzielono na trzy paragrafy. W pierwszym zamieszczono przepisy ogólne, drugi dotyczył porządku dziennego, w trzecim opisano obowiązki wobec innych ${ }^{32}$.

${ }^{29}$ Art. 1, pkt 2, Regolamento del Pontificio Collegio Polacco. Istituto in Roma, Roma 1866. APKP, sygn. I 25.1, s. 3. Por. M. StęPIEŃ, Prawa i obowiqzki alumnów w Regulaminie Papieskiego Kolegium Polskiego w Rzymie z 1866 r., Prawo Kanoniczne 55(2012), nr 1, s. 84.

${ }^{30}$ Pkt 3, 7, Statuta Pontificii Collegia Polonorum in Urbe (uwierzytelniony odpis). Rzym, 12-12-1960. Ad N. 3217/60/P. APKP, sygn. III 28.2, s. 1-2.

${ }^{31}$ Art. 1, pkt 4, Regolamento del Pontificio Collegio Polacco. Istituto in Roma, Roma 1866. APKP, sygn. I 25.1, s. 35.

${ }^{32}$ Por. pkt 21-51, Regulae ab alumnis Pontificii Collegia Polonorum in Urbe servandae (uwierzytelniony odpis). Rzym, 12-12-1960. Ad N. 3217/60/P. APKP, sygn. III 28.2, s. 7-13. 


\subsection{Normy ogólne}

Student, który został przyjęty do Kolegium miał obowiązek stawić się w Rzymie przed początkiem października, posiadać ubranie na cały rok oraz określoną sumę pieniędzy, wystarczającą na powrót do ojczyzny $\mathrm{i}$ inne wydatki. Kwota ta obowiązkowo miała być zdeponowana u ekonoma Kolegium ${ }^{33}$. Kapłan, który ubiegał się o przyjęcie, musiał uzyskać zgodę Prymasa Polski, następnie zgłosić się do Kolegium pierwszego października. W trakcie studiów nie mógł przebywać w Kolegium w czasie wakacji (15 lipca - 1 października), zobowiązany był wówczas zapewnić sobie inne miejsce pobytu we własnym zakresie ${ }^{34}$.

Alumni zarówno w życiu duchowym, jak i w procesie kształcenia intelektualnego, zobowiązani byli do czynienia stałych postępów, zważając, aby swoim zachowaniem nie utrudniać życiakolegom ${ }^{35}$. We wspólnocie ważnym celem było zapewnienie wszystkim podobnych, w miarę możliwości wygodnych warunków życia. Każdy był zobowiązany zachowywać czystość we własnym pokoju i budynku, dbać o swoje ubrania oraz o inne rzeczy, zarówno własne, jak i wspólne. Nie można było wchodzić do cudzego pokoju bez zaproszenia gospodarza $^{36}$. Zachęcano alumnów, aby pamiętali o ćwiczeniach fizycznych - co było nowością, a także, by dbali o zdrowie. W razie złego samopoczucia należało niezwłocznie powiadamiać prefekta. Chory nie mógł, bez zezwolenia przełożonego, wzywać lekarza do Kolegium ${ }^{37}$. Student mógł wychodzić do uniwersytetu, na spacer lub w każdym innym celu tylko z socjuszem, wcześniej uzyskawszy zgodę przełożonego. Powrót

${ }^{33}$ Według Regulaminu z 1866 r. zdeponowana suma powinna wystarczyć na pokrycie kosztów czasowego wyjazdu do ojczyzny oraz utrzymanie studenta w Kolegium przez okres semestru. Por. art. 2, pkt 4, Regolamento del Pontificio Collegio Polacco. Istituto in Roma, Roma 1866.APKP, sygn. I 25.1, s.6.

${ }^{34}$ Pkt 3-4, Regulae ab alumnis Pontificii Collegia Polonorum in Urbe servandae (uwierzytelniony odpis). Rzym, 12-12-1960. Ad N. 3217/60/P. APKP, sygn. III 28.2, s. $1-2$.

${ }^{35}$ Pkt 21, tamże, s. 7.

${ }^{36}$ Pkt 22-23, tamże.

${ }^{37}$ Pkt 24, tamże. 
do Kolegium musiał nastapić przed nieszporami. W dniach świątecznych dopuszczano możliwość wychodzenia alumna na prośbę jego ordynariusza albo z innej poważnej przyczyny - po uzyskaniu zgody. Przyczyną usprawiedliwiająca mogło być spełnianie praktyk religijnych i uczestniczenie we Mszy św. poza Kolegium. W takim przypadku nie było konieczności wychodzenia z socjuszem ${ }^{38}$.

Zgodnie z normami zawartymi w pierwszym Regulaminie z XIX w., wyjście alumna z Kolegium odbywało się tylko za zgodą rektora. Natomiast w omawianych dokumentach mówi się tylko o zgodzie, bez doprecyzowania, przez kogo miałaby być wydawana ${ }^{39}$. Na przełomie XIX i XX w. określono, że alumni mogli wychodzić do miasta bramą główną w gronie przynajmniej trzech osób, a księża dwóch ${ }^{40}$. Regulamin z 1909 r. zezwalał, by alumn wychodził sam w celu spotkania się ze swoim biskupem lub inną osobą „kościelną”, z którą miał specjalne relacje, oczywiście po uzyskaniu pozwolenia rektora. Zasada ta dotyczyła także krewnych. W innych wypadkach musiał mieć socjusza wyznaczonego przez rektora ${ }^{41}$.

Regulamin z 1960 r. zabraniał klerykom udawania się do teatru i kina, gdy spektakle odbywały się w salach publicznych, oraz do restauracji i karczm² ${ }^{42}$ Był to nowy szczegółowy zakaz, w normach poprzednio obowiązujących miejsca niedozwolone określano ogólnie, bez ich precyzowania ${ }^{43}$.Poza czasem rekreacji i spaceru studentów

\footnotetext{
${ }^{38}$ Pkt 27, 29, tamże, s. 8.

${ }^{39}$ Por. art. 10, pkt 23, Regolamento del Pontificio Collegio Polacco. Istituto in Roma, Roma 1866. APKP, sygn. I 25.1, s. 34.

${ }^{40}$ Por. pkt 52, Przepisy Kolegium Polskiego w Rzymie, Kraków 1894. APKP, sygn. I 26, s. 12.

${ }^{41}$ Pkt 35, Regolamento per gli alumni del Pontificio Collegio Polacco, Roma 1909. APKP, sygn. I 27.1, s. 7.

${ }^{42}$ Pkt 28, Regulae ab alumnis Pontificii Collegia Polonorum in Urbe servandae (uwierzytelniony odpis). Rzym, 12-12-1960. Ad N. 3217/60/P. APKP, sygn. III 28.2, s. 8.

${ }^{43}$ W Regulaminie z 1866 r. nakazywano unikać: zebrań publicznych i miejsc, gdzie zwykle gromadziło się wielu ludzi, spożywania obiadu poza Kolegium i posilania się w miejscach publicznych w mieście i poza miastem, udawania się do miejsc nieodpowiednich dla duchownych. Art. 3, § 3, pkt 3, 4; art. 5, pkt 10, Regolamento del Pontificio Collegio Polacco. Istituto in Roma, Roma 1866.APKP, sygn. I 25.1, s. 11-12.
} 
obowiązywało milczenie, co miało sprzyjać zdobywaniu wiedzy ${ }^{44}$. Przebywanie w kuchni Kolegium bez zgody ekonoma było zabronione. Nie można było zabierać żywności do pokoi i jej tam przechowywać. Rygorystycznie zakazane było posiadanie alkoholu ${ }^{45}$. Miejscem rekreacji była specjalnie przeznaczona do tych celów aula, ogród lub taras, ale nigdy prywatny pokój. W Regulaminie podkreślono, że klerycy powinni wystrzegać się palenia tytoniu, a przynajmniej starać się ograniczać to „przyzwyczajenie" ${ }^{46}$.

\subsection{Porządek dzienny}

Alumni mieli wstawać rano na dźwięk dzwonka i zwracać się myślami do Boga. Bez specjalnego zezwolenia nikt nie mógł wstać przed dzwonkiem. Następnie wszyscy udawali na modlitwy poranne i Mszę święta, po czym przechodzono do refektarza na śniadanie. Po posiłku przewidziany był czas na porządkowanie własnego pokoju ${ }^{47}$. Studenci zobowiązani byli udawać się do uniwersytetu $\mathrm{w}$ towarzystwie co najmniej jednej osoby - nigdy pojedynczo. W drodze powrotnej nie mogli wchodzić do sklepów ani spacerować po mieście bez zezwolenia przełożonego ${ }^{48}$.

Po rekreacji południowej była przewidziana nieprzekraczająca godziny,„sjesta”. W tym czasie należało zachować ciszę, aby umożliwić

${ }^{44}$ Pkt 30, Regulae ab alumnis Pontificii Collegia Polonorum in Urbe servandae (uwierzytelniony odpis). Rzym, 12-12-1960. Ad N. 3217/60/P. APKP, sygn. III 28.2, s. 9. W tekście Regulaminu posłużono się cytatem ze św. Karola Boromeusza [,„...silentium per multum ad pacispietatis que conservationem conferat"].

${ }^{45}$ Pkt 36, Regulae ab alumnis Pontificii Collegia Polonorum in Urbe servandae (uwierzytelniony odpis). Rzym, 12-12-1960. Ad N. 3217/60/P. APKP, sygn. III 28.2, s. 10 .

${ }^{46}$ Pkt 39-40, tamże. W Regulaminie z 1909 r. także zezwalano na palenie tytoniu, ale tylko we własnym pokoju i pod warunkiem, że nie ma w nim w danym momencie innych osób. Por. pkt 32, Regolamento per gli alumni del Pontificio Collegio Polacco, Roma 1909. APKP, sygn. I 27.1, s. 6.

${ }^{47}$ Pkt 31-33, Regulae ab alumnis Pontificii Collegia Polonorum in Urbe servandae (uwierzytelniony odpis). Rzym, 12-12-1960. Ad N. 3217/60/P. APKP, sygn. III 28.2, s. 9.

${ }^{48}$ Pkt 34, tamże. 
wypoczynek innym ${ }^{49}$. Po raz pierwszy była mowa o wypoczynku popołudniowym w Przepisach Kolegium wydanych w końcu XIX w. Wtedy przewidziano na ten cel godzinę po rekreacji poobiedniej w dniach od 3 maja do 14 września każdego roku. W tym czasie alumni mogli się położyć, w budynku należałozachować milczenie, nikogo nie należało odwiedzać ani przemieszczać się głośno po korytarzach. Takie uregulowania powtórzono w Regulaminie wydanym w 1909 r. ${ }^{50}$ Natomiast w omawianych dokumentach cisza w budynku obowiązywała dodatkowo w czasie przeznaczonym na prywatne zajęcia studentów ${ }^{51}$. Na spacer musieli chodzić wszyscy, z wyjątkiem tych, którzy grali w tym czasie w piłkę w ogrodzie Kolegium, lub mieli inną poważną przyczynę uniemożliwiającą wypełnienie tego obowiązku ${ }^{52}$. Według wcześniej obowiązujących norm, studenci udawali się w towarzystwie prefekta i grupy współtowarzyszy na spacer, podczas którego obowiązywało milczenie. Nikt nie mógł pozostać w domu w czasie spaceru, nie uzyskawszy zgody przełożonego ${ }^{53}$.

W Regulaminie z 1960 r. jednoznacznie określono, że po nieszporach, rachunku sumienia oraz modlitwach wieczornych niezwłocznie należało udać się do swojego pokoju, nie można już było załatwiać jakichkolwiek spraw. Po sygnale dźwiękowym gaszono światło, po czym natychmiast należało udać się na spoczynek. Od tego momentu obowiązywało milczenie i tylko za specjalnym pozwoleniem można było po ciszy nocnej udać się do swego pokoju ${ }^{54}$. Zasady obowiązu-

${ }^{49}$ Pkt 41, tamże, s. 11.

${ }^{50}$ Por. pkt 45, Przepisy Kolegium Polskiego w Rzymie, Kraków 1894. APKP, sygn. I 26, s. 11; Orario pomeridiano, Regolamento per gli alunni del Pontificio Collegio Polacco, Roma 1909. APKP, sygn. I 27.1, s. 13.

${ }^{51}$ Pkt 43, Regulae ab alumnis Pontificii Collegia Polonorum in Urbe servandae (uwierzytelniony odpis). Rzym, 12-12-1960. Ad N. 3217/60/P. APKP, sygn. III 28.2, s. 11.

${ }^{52}$ Pkt 42, tamże.

${ }^{53}$ Art. 10, pkt 19-22, Regolamento del Pontificio Collegio Polacco. Istituto in Roma, Roma 1866. APKP, sygn. I 25.1, s. 33. Por. M. STĘPIEŃ, Prawa i obowiazki alumnów w Regulaminie Papieskiego Kolegium Polskiego w Rzymie z 1866 r., Prawo Kanoniczne 55(2012), nr 1, s. 94.

${ }^{54} \mathrm{Pkt} 44$, Regulae ab alumnis Pontificii Collegia Polonorum in Urbe servandae 
jące studentów w czasie udawania się na spoczynek były podobne do opisanych w pierwszym Regulaminie Kolegium ${ }^{55}$.

\subsection{Obowiązki alumna względem personelu Kolegium i studentów}

Ostatni paragraf w trzeciej części omawianego Regulaminu zawiera siedem punktów i jest zatytułowany „o obowiązkach względem innych"56. W przepisach tych zobowiązywano alumnów, by darzyli szacunkiem i zaufaniem moderatorów Kolegium, byli im posłuszni i wszelkie ich uwagi przyjmowali z życzliwością i zrozumieniem ${ }^{57}$. Polecenia i prośby prefekta alumnów, ceremoniarza, kantora należało wykonywać $\mathrm{w}$ duchu posłuszeństwa i zrozumienia ${ }^{58}$. Obowiązywała generalna zasada, że studenci nie mogli przebywać w części budynku zajmowanej przez siostry zakonne bez pozwolenia przełożonego. Wyjątkiem były sytuacje, w których osoby pełniące funkcje liturgiczne mogły udawać się tam w celu załatwiania pilnych spraw, po czym zobowiązane były do niezwłocznego opuszczenia tego miejsca ${ }^{59}$. Studenci nie mogli o nic prosić pracowników Kolegium ani innych pracujących czasowo na terenie Kolegium osób ani wydawać im poleceń bez pozwolenia przełożonego. Zakazane było też zapraszanie ich do prywatnych pokoi ${ }^{60}$. Przyjmowanie gości z zewnątrz dozwolone było tylko w czasie wolnym w rozmównicy, po wcześniejszym otrzymaniu zgody. Zaproszenie bliskich osób do własnego pokoju było możliwe tylko po otrzymaniu specjalnego zezwolenia ${ }^{61}$.

(uwierzytelniony odpis). Rzym, 12-12-1960. Ad N. 3217/60/P. APKP, sygn. III 28.2, s. 11.

${ }^{55}$ Por. art. 10, pkt 11-12, Regolamento del Pontificio Collegio Polacco. Istituto in Roma, Roma 1866.APKP, sygn. I 25.1, s. 31-32.

${ }^{56}$ Por. pkt 45-51, Regulae ab alumnis Pontificii Collegia Polonorum in Urbe servandae (uwierzytelniony odpis). Rzym, 12-12-1960. Ad N. 3217/60/P. APKP, sygn. III 28.2, s. 11-13.

${ }^{57}$ Pkt 45-46, tamże, s. 11-12.

${ }^{58}$ Pkt 47, tamże, s. 12.

${ }^{59}$ Pkt 48, tamże.

${ }^{60}$ Pkt 49, tamże.

${ }^{61}$ Pkt 50, tamże, s. 13. 
Rektor miał prawo usunąć studenta z Kolegium, jeśli ten nie mógł opanować wymaganej wiedzy, nie przestrzegał dyscypliny, był niedbały w swoim zachowaniu. Aby to zrobić, rektor musiał wysłuchać opinii deputatów i zakomunikować swoją decyzję biskupowi ordynariuszowi alumna $^{62}$. Procedura usunięcia studenta $\mathrm{z}$ Kolegium została zmieniona w stosunku do obowiązującej od połowy XIX w. Wówczas rektor na usunięcie studenta musiał uzyskać zgodę protektora Kolegium. Według norm z $1960 \mathrm{r}$. do usunięcia wystarczyły konsultacje rektora z deputatami ${ }^{63}$.

Na końcu omawianych dokumentów umieszczono formułę stwierdzająca, iż żadne nowe prawa i zwyczaje nie mogą być w Kolegium wprowadzane, a istniejące zawieszane lub zmieniane. Alumni mieli być zaznajamiani $\mathrm{z}$ obowiązującymi przepisami i wykonywać je z wiarą i gorliwością. Każdy student, który nie stosowałby się do norm zawartych w Statucie i Regulaminie, co w konsekwencji przeszkadzałoby w odpowiednim przygotowaniu się do kapłaństwa, musiał być świadomy, że może zostać usunięty z Kolegium, zgodnie z kan. 137164. Postanowienia końcowe, jak wynika z treści dwóch ostatnich punktów,

${ }^{62}$ Pkt 13, Statuta Pontificii Collegia Polonorum in Urbe (uwierzytelniony odpis). Rzym, 12-12-1960. Ad N. 3217/60/P. APKP, sygn. III 28.2, s. 3.

${ }^{63}$ Procedury usuwania alumnów z Kolegium określone w Regulaminie z 1866 r. były bardziej szczegółowe. Pierwszych sześć miesięcy pobytu studenta w Kolegium było okresem próby. W tym czasie, jak i przez cały okres kształcenia, alumni mogli zostać usunięci przez przełożonych z następujących powodów: poważnych problemów ze zdrowiem, które uniemożliwiałyby kontynuowanie studiów; braku dostatecznych postępów w nauce; braku powołania do stanu duchownego; nieprzestrzegania dyscypliny w Kolegium, mimo powtarzanych upomnień; postawy nieposłuszeństwa, nieopanowania w stosunku do przełożonych oraz zakłócania porządku w Kolegium; braku zadowalających postępów w kształtowaniu postawy i charakteru. Art. 2, pkt 1415, RegolamentodelPontificioCollegioPolacco. Istituto in Roma, Roma 1866. APKP, sygn. I 25.1, s. 7.

${ }^{64}$ "Can. 1371 E Seminario dimittantur dyscoli, incorrigibiles, seditiosi, ii qui ob mores atque indolem ad statum ecclesiasticum idonei non videantur; itemque, qui in studiis adeo parum proficient ut spes non affulgeat eos sufficientem doctrinam fore assecuturos; praesertim vero statim dimittantur qui forte contra bonos mores aut fidem deliquerint”.CIC 1917. w: AAS 9 II (1917), s. 266. 
odnoszą się do norm zawartych zarówno w Statucie, jak i w Regulaminie Papieskiego Kolegium Polskiego z 1960 r ${ }^{65}$.

\section{Zakończenie}

Statut i Regulamin Papieskiego Kolegium Polskiego w Rzymie Stolica Apostolska zatwierdziła w końcu 1960 r. Kolegium określono instytucją posiadającą kościelną osobowość prawną, mającą za zadanie kształcenie i przygotowywanie studentów z polskich diecezji do przyjęcia święceń kapłańskich.

Omawiane dokumenty odnosiły się przede wszystkim do alumnów przygotowujących się do przyjęcia święceń kapłańskich, dlatego położono w nich nacisk na studia filozoficzne i teologiczne. Przez prawie cały okres obowiązywania Statutu i Regulaminu z 1960 r. w Kolegium zamieszkiwali jednak księża, którzy podejmowali studia specjalistyczne z zakresu różnych dyscyplin, zależnie od decyzji ich biskupów, a nie tylko filozoficzne, teologiczne czy prawne, jak precyzował pierwszy Regulamin Kolegium z połowy XIX w. Każdy kapłan, który ubiegał się o przyjęcie do Kolegium, musiał uzyskać zgodę kardynała Prymasa Polski.

Statut stanowił, że alumni mieli odznaczać się powołaniem do służby Bożej, wzorowo postępować, mieć nieskazitelny charakter, dobre zdrowie i potrzebne zdolności. W Regulaminie z 1960 r. zwrócono szczególną uwagę na znaczenie formacji duchowej studentów. Podkreślono, że w misji powołania bardzo ważną rolę odgrywa dążenie kleryka czy kapłana do świętości poprzez prowadzenie odpowiedniego życia duchowego.

Księża zamieszkujący w Kolegium byli zobowiązani do nieustannego pogłębiania życia duchowego i wytrwałego zdobywania wiedzy intelektualnej, zgodnie z zasadami określonymi przez Stolicę Apostolską i swoich biskupów, czynienia wszystkiego dla chwały Bożej, zbawienia dusz i dobra swojej ojczyzny. Mieli oni obowiązek codzien-

${ }^{65}$ Pkt 52-53, Regulae ab alumnis Pontificii Collegia Polonorum in Urbe servandae (uwierzytelniony odpis). Rzym, 12-12-1960. Ad N. 3217/60/P. APKP, sygn. III 28.2, s. 14. 
nego celebrowania Mszy św. i odprawiania dziękczynienia. Wszyscy studenci na początku każdego roku zobowiązani byli do odbycia rekolekcji trwających pięć pełnych dni, zamiast dotychczasowych ośmiu. Raz w miesiącu odbywał się dzień skupienia, a co najmniej raz na tydzień alumni zobowiązani byli przystępować do sakramentu pokuty u wybranego spowiednika lub kierownika duchowego. Także w tym przypadku postanowieniem Regulaminu skrócono ten czas o ponad połowę.

Studenci mieli za zadanie uczyć się rezygnować z własnych dążeń oraz z pokorą poświęcać się pracy na większą chwałę Bożą i dla zbawienia dusz. Odbywali studia na Uniwersytecie Gregoriańskim lub na innych kościelnych uczelniach w Rzymie. Od początku XX w. obowiązywała zasada, że mieszkańcy Kolegium mogli podejmować studia tylko na Uniwersytecie Gregoriańskim. W omawianym Regulaminie umożliwiono studiowanie także na innych rzymskich uczelniach kościelnych. Zakres studiów zawsze musiał być konsultowany z rektorem Kolegium. Regulamin z 1960 r. stanowił, że studenci w Kolegium powinni posługiwać się przede wszystkim językiem polskim, doskonaląc go w piśmie i mowie,ale również, by często korzystali z języka łacińskiego i włoskiego. Ostatnią część Regulaminu poświęcono zasadom zachowania dyscypliny, określając tam ogólne prawa i obowiązki alumna względem personelu Kolegium oraz innych studentów, zawarto tam również wskazania dotyczące porządku dziennego.

\section{Rights and responsibilities of alumni in the bylaws and Statutes of the Polish Pontifical College in Rome in 1960}

At the end of 1960, the Holy See approved new Bylaws and Statutes of the Pontifical Polish College in Rome. The Polish Pontifical College was identified as an institution having ecclesiasticallegal personality, which is responsible for educating and preparing students from Polish dioceses to become ordained as priests.

Primarily, these documents relate to students who were preparing to receive the sacrament of Holy Orders. A great emphasis was placed on the study of philosophy and theology. Since 1963, only priests resided at the Polish Pontifical College that were sent by their diocesan bishops for specialized studies in Rome.

The Bylaws and Statutes require that the students show a vocation to the service of God, be exemplary role models, have good character, good health and needed talents. 
Special attention was given to the importance of spiritual development of the students. The bylaws emphasize the importance of the seminarian's pursuit of his vocation or a priest's holiness, by maintaining an appropriate spiritual life. Students are also required to constantly and consistently gain intellectual knowledge, in accordance to the bylaws laid down by the Holy See and their bishops. The last part of the Bylaws stresses the importance of discipline, stating the general standards, the responsibilities of the alumni in regards to College personnel and students, as well as providing the daily agenda. 